まだまだ明確な解答を出すのは難かしく, 今後の研究発 表に期待したい. 尚, 基礎的検討項目については, 満足 できる結果であった。

演題 9 は, $\mathrm{T}_{3}$ up take の binder となるアルブミンと チャコールの相異による，NTIにおける成績結果が報告 され, $\mathrm{AT}_{3} \mathrm{U}$ から算出した $\mathrm{FT}_{4} \mathrm{I}$ がより正確な $\mathrm{FT}_{4}$ の間 接的指標となり得ることが示唆され, 大変興味ある知見 を示してくれた。ただ，座長としては， $\mathrm{T}_{3}$ up take その ものは，甲状腺疾患に関しては，他のホルモンを測定す ることにより，おおむね適切な診断をくだせる現状であ るとの考えより， $\mathrm{T}_{3}$ up take そのものの限界等を示すこ とにより，なぜ, binder が異なることによって相異が出 てきたのかを追求することにより，今後の研鑚を期待し ている.

全体のまとめとしては, Kit の基礎的・臨床的検討は大 変重要な事柄であるが, メーカーあるいは各診療科との 協力あるいは各施設間の連携により，Kitの開発の方向 にも目を向けて戴きたいと思う。

治 療

座長 阿部勝彦（国立札幌病院）

\section{0. 吸収線量の新標準測定法に関する当施設の対応} 旭川医科大学医学部附属病院放射線部 ○西部茂美・平田良昭

〔目的〕日本医学放射線学会物理部会上り, 吸収線量 の計算法が改訂され, 光子と電子線に共通して成り立つ 統一式の導入，並びに新しい物理データや擾乱係数の採 用にともない, JARP 型線量計を保有しない当施設の対 応について，以下の項目について検討・考察したので報 告する.1. ${ }^{60} \mathrm{Co}$ 空中組織吸収線量測定 2. $10 \mathrm{MV} \mathrm{X}$ 線 のエネルギー校正扔よび出力測定 $3.6 \sim 15 \mathrm{M}_{\mathrm{e}} \mathrm{V}$ 電 子線のエネルギー校正および出力測定

〔結果〕電離箱の種類とその材質により, $A_{c}, A_{w}$ 等を 決定し，自己の測定データを正確なものとし，JARP 型 以外の線量計でも, 線量測定の精度・正確度の向上につ とめることができた。

\section{1. 放射線治療計画用 CT 装置の開発（その 1 ） \\ CR 画像を用いたプランニング}

北海道大学医学部附属病院放射線部 ○渡辺良晴・藤田勝久・古家輝夫 山口 恵

同放射線科

鎌田 正・辻井博彦・入江五朗

RT-CT システムは，CT 情報を放射線治療に有効に 利用することを目的に開発された。装置は，ターゲット
の設定, 照射条件の最適化，3 次元の線量分布計算，患 者体表面へのマーキングなど従来のX線シュミュレー夕 の機能と, 線量計算システムの機能を合わせ持っている.

このシステムの機能の一つである CR 画像を用いる治 療計画は，CT 画像を用いて幾何学的な補正を行うこと により，従来のX線シュミュレータと同じような治療計 画が可能である。この方法は時間がかからず簡単である にもかかわらず, CT 画像上で治療線錐を確認できるた め, 平面の X線写真から照射野を決定するよりも精度良 く治療計画が行える.

\section{2. 放射線治療計画におけるコーリレイト機能（GE 社} CT9800 ソフト）の有用性について 市立函館病院

$$
\begin{aligned}
& \text { ○角田文男 } \cdot \text { 村屋 保 } \cdot \text { 石田和志 } \\
& \text { 三上 仁・橋本泰弘・長谷川幸男 } \\
& \text { 計良明伸 } \cdot \text { 田井中恵一 }
\end{aligned}
$$

〔目的〕放射線治療において CT は照射条件の最適化 等のため絶対に不可欠なものである。そこで今回 $\mathrm{GE}$ 社 CT9800のソフト,コーリレイト機能が放射線治療計画を 行う上で有用であったのでここに報告する。

〔結果および考察〕アクシャル画像に任意の関心領域 を設定するとその最大外側を点としてスカウト画像上に 誤差なく投影していた，そのため放射線治療計画におけ る照射野の設定等に有用であると思われた。しかし患者 に動きのある場合は詥差要因が大きくなり注意を要する こと,アクシャル画像に対する関心領域の設定に困るこ とがあること，またスカウト画像の照射野を患者に直接 投影させることができないため今後これらの改善が望ま れる。

\section{座長集約}

治療の演題は 3 題と少なかった。北海道内における医 療用加速器の設置台数も急増していることから, 次回以 降一題でも多くの発表を望みたい.

演題10は新標準測定法の導入に伴う対応についての報 告であった，JARP 型線量計を持たない施設では，その 線量計ごとの対応が要求され, 物理定数の変更など一見 従来の標準測定法から大きく変化したように思われる部 分もあることから切替は容易ではない. JARP 型電離箱, シャロー型電離箱を購入することが対応を容易にする一 方法であるが，予算面からの制約も大きいと考えられる. なお，今回対称となった電離箱は壁材がナイロンにグラ ファイトをコーティングしたものであり前述した理由に より，低エネルギー電子線に対しシャロー型電離箱は使 用していないとのことである。 
演題11は世界で 2 台，ソフト的には 1 台といわれる新 しい治療計画装置についての発表であり，すべての面で 興味深かった。試作機ということで CT，線量分布計算 機, シュミレータ，データファイルなどの各装置間での デー夕転送，操作性などの問題，さらに放射線治療計画 により有用なソフトの開発など, 苦労が多いと思われる が，その困難を克服して優秀な装置を開発されることを 期待する.

演題12は CT 装置附属ソフトのコーリレイト機能が放 射線治療計画に有用であるか否かについての報告であつ た。渡辺（北大）より CT と治療装置の幾何学的な違い により誤差が生ずるので注意を要するとの指摘があった が，その点は考慮しているとのことであった。関心領域 の設定が限定される点，投影機能がないなど問題点もあ るが，既存の CT 装置の附属ソフトの利用により，より 良い放射線治療計画が可能であるという内容であった。 今後, バージョンアップに使用者の意見を反映し，さら に有用なソフトが提供されることを期待する。

パソコン利用

座長 栗田政一（帯広厚生病院）

\section{3.（第 2 報）重症弁膜症 SJM 弁置換後の Computer を} 利用しての follow-up

北海道大学医学部附属病院放射線部
○横山英辰 - 炭田修身・坪田秀一
菊池 務

弁膜症によって機能低下した心臓弁を人工弁に置換す る治療が行われている，しかし置換した人工弁は経年的 に機能不全に陷る可能性があり，弁の follow-up が重要 である. follow-up 検査に弁の Cine-radiograph から人 工弁の弁体の開閉角を計測することを行っている．しか し，計測は手作業であり，data 管理も人が行っている. 今回，その作業の Computer 化を試みた。その結果，計 測はスピーディに行え, data 検索も早く, 容易になっ た。また，撮影角度も入力しておくことで， 2 回目以降 の検査時の弁捜しにむだな被曝をさけられ検查時間も短 縮された。

\section{Repeat Film に関する考察}

医療法人医仁会中村記念病院

○加藤徳史・柴田裕正・富樫一彦 佐藤勝保

〔目的〕日常業務に扔いて条件不良・整位不良・機器 不調または人為的原因による Repeat Filmの取り扱い は，技術面・経済面において直面する 1 つの問題点であ る。そこでわれわれは, 昭和 61 年度私的病院学会におい
て報告した同題目の内容をもとに，新たに 1 年分のデー 夕を追加し，Repeat Film に関して検討，および考察を 加えたので報告する。

〔結果〕再撮率全般に関しては，ミーティングなどに よる意識の向上のため，減少傾向が見られた。また，前 回の報告において指摘のあった新卒者の再撮に関しても， 計画的なトレーニングのために短期間で再撮率が減少し た.

\section{座長集約}

われわれ，医療從事者にとってコンピュータの存在は ごく自然であり，膨大なデ一夕収集・整理・解析作業の 良きパートナーであることは誰もが承知するところであ る、データのバックグラウンドが臨床統計であれ画像工 学であれ目的は情報の有効利用にあり，いかに最大効率 で精度良く事象を抽出・表現できるかに興味が注がれて いる.

今回のパソコン利用の 4 題では，われわれ放射線技師 が施設の枠を離れて互いに情報交換(PRGRAM, DATA etc.) の必要性があることを実感させられた。

演題13 (北大) 横山君の報告は, SJM 弁置換後の人工 弁動作状況を FOLLOW-UPするためのSYSTEM 構 築である.臨床データの管理 SYSTEM は既成のものが 皆無であり，対照・規模に応じて設計しなければならず 記録形式も充分に検討され将来の変更に対処できる方法 がとられる。ここでは使用例が報告されたにとどまった が，症例数が蓄積された場合の SYSTEM 運用が今後興 味がもたれる。

演題14（帯広厚生）太田君は管理区域内診療従事者の 被曝線量を収集・管理する SYSTEM を設計し，実際の 稼働状況を報告した，運用上の問題点は唯一，測定器の 特性である. REM MASTER は元来高レベル放射線の モニタリングに使用されシリコン半導体検出器である. 実効感度は80 keV が下限であり出荷状態では $\mathrm{X}$ 線被曝 モニタには使用できず,富士電気計装 K.K に協力頂き感 度を $60 \mathrm{keV}$ まで調整し検討を進めている.調整後のモニ 夕結果を分析できしだい報告したい.

演題15（中村記念）加藤君は再撮状況を分析し業務に 反映させることの必要性と処理のための記録書式につい て検討・報告した．座長の勤務施設でも 1 日1000〜 1500 枚のフィルムを処理しロスも月あたりかなり計上してい るが，原因追及・対策はしても細部の分析ができるほど ロス伝票処理の SYSTEM 化は難しい. 状況の正確な分 析にはそれなりの項目と，長期間に正確度が維持できる 入力方法が必要になる。パソコンはこの演題のように， 